$\begin{array}{ll}\text { Abstracta Iranica } & \begin{array}{l}\text { Abstracta Iranica } \\ \text { Revue bibliographique pour le domaine irano-aryen }\end{array} \\ & \text { Volume } \mathbf{3 7 - 3 8 - 3 9} \text { | } 2018 \\ \text { Comptes rendus des publications de 2014-2016 }\end{array}$

\title{
Sergej Vsevolodovič Kullanda. Skify: jazyk i ètnogenez [The Scythians: Language and ethnogenesis]
}

\section{Rüdiger Schmitt}

\section{(2) OpenEdition}

\section{Journals}

Electronic version

URL: http://journals.openedition.org/abstractairanica/42464

DOI: $10.4000 /$ abstractairanica.42464

ISBN: 1961-960X

ISSN: 1961-960X

Publisher:

CNRS (UMR 7528 Mondes iraniens et indiens), Éditions de l'IFRI

\section{Electronic reference}

Rüdiger Schmitt, «Sergej Vsevolodovič Kullanda. Skify: jazyk i ètnogenez [The Scythians: Language and ethnogenesis] », Abstracta Iranica [Online], Volume 37-38-39 | 2018, document 1, Online since 10 March 2018, connection on 28 September 2020. URL : http://journals.openedition.org/

abstractairanica/42464; DOI : https://doi.org/10.4000/abstractairanica.42464

This text was automatically generated on 28 September 2020 .

Tous droits réservés 


\title{
Sergej Vsevolodovič Kullanda. Skify: jazyk i ètnogenez [The Scythians: Language and ethnogenesis]
}

\author{
Rüdiger Schmitt
}

\section{REFERENCES}

Sergej Vsevolodovič Kullanda. Skify: jazyk i ètnogenez [The Scythians: Language and ethnogenesis]. Moskva: University Dmitrija Požarskogo, 2016, 215 p.

1 In the present book its author, who in the last ten years had published about a dozens of papers on the Scythians and their language, put his findings together in monographic form. And the detailed index of the words and forms discussed therein ( $\mathrm{p}$. 186-210) makes the contents easily accessible to the reader, who by the substantial bibliography (p. 157-185) gets also much information esp. on the Russian literature about the Scythians. Ch. 1 on the Scythian prehistory (p. 15-27) de facto describes, what historical linguistics could establish about the prehistory of the speakers of the IndoIranian and Common Iranian languages. In ch. 2 on Scythian culture and language (p. 28-96) follows an analysis of the written and the material evidence, from which the author concludes that the Scythians spread from the Aral Sea region. The main part of this chapter is a glossary of the Scythian words attested with more or less certainty (p. 41-96), in which one finds discussed, apart from the Herodotean evidence, also the relevant glosses of Hesychius and a multitude of names (personal names, toponyms, hydronyms, etc.) attested in later authors and in inscriptions found in Scythian kurgans or on various objects. Ch. 3 on Scythian history as seen in the light of language (p. 97-145) is an attempt to make out the essentials of Scythian historical phonology and to identify Scythian linguistic contacts with other languages. The author in part works with new sound laws not yet ascertained and thus maintains, contrary to the 
common opinion, that the Scythian language differs markedly from Sarmatian (p. 145). In all, there remain many unsettled questions, and the discussion must go on.

\section{AUTHORS}

\section{RÜDIGER SCHMITT}

Laboe 